items follows. Many of the latter seem more pertinent to the subject matter of the book, and more necessary to qualify and summarize because they are less familiar to the average librarian.

As a brief, introductory volume to certain of the problems encountered in the education of librarians, this text will no doubt serve a useful role. One might quarrel with the title, since there are other major problems which have not been included. For instance, are there no difficulties in the training of reference librarians, catalogers and administrators? In a second edition the present title might be amended so as to suggest more clearly the trend of the contents.-Harriet D. MacPherson, Drexel Institute of Technology.

\section{Rare Bibles}

Rare Bibles; an Introduction for Collectors and a Descriptive Checklist. By Edwin A. R. Rumball-Petre. New York, Philip C. Duschnes, 1954. 53 p. $\$ 6.00$.

This is a revised edition of the work of the same title issued in 1938. Its compiler, the late Rev. Rumball-Petre, who died in July, I954, is said to have been the only bookman who dealt exclusively with rare editions of the Bible.

In scope and arrangement the two editions are similar, beginning with "Incunabula," continuing with "Polyglots," "English Bibles," "Bibles Printed in America," "Hebrew, Greek and Latin Bibles," and "Bibles in Modern Languages other than English." The sections for "Miscellaneous Bible Portions" and "Curious Editions of the Bible" cut across the other categories both in time and language.

There are 378 items listed as against 345 in the first edition, the incunabula section, increased from twenty to forty items, being responsible for the greatest number of additions. Aside from this, the main difference between the two editions is in the character of the notes. In the first edition there were occasional references to prices but these have been omitted in the revision and the descriptions are limited to bibliographical and historical data.

Revision barely touched the bibliography. Only a half-dozen additions appear and one of these was published in 1838 . It seems strange that it was added while such a worth- while aid to the modern collector as the Pierpont Morgan Library's catalog of their exhibition of Bibles in 1947 was not included. The number of volumes of the Gesamtkatalog has not been brought up to date nor were later editions of works mentioned that have been brought out in new editions since 1938 .

The compiler made it clear that the basis for his selection was rarity coupled with some historic or distinctive feature. But for some unexplained reason he did not include a single one of the Bibles famous because of their illustrations, for example, the Cologne Bible, the Lübeck Bible or the Malermi Bible. Among famous modern editions Bruce Roger's Lectern Bible is listed but not his World Bible. However it is individual taste that makes collectorship interesting and this is a useful handbook for a collector or historian of printing.

The two editions are witnesses of the change in book production during these last two decades. The 1938 publication of 500 copies reflects the fine printing of the day in the quality of the paper, the generous margins, and the eight illustrations which enliven the text. The 1954 edition of 600 copies has a slightly longer text compressed into ten less pages by crowding more words on a page of less attractive paper; there are no illustrations and the price is exactly double that of the 1938 edition.-Bertha M. Frick, School of Library Service, Columbia University.

\section{Book Collectors}

\section{Private Book Collectors in the United States and Canada. Ioth rev. ed. New York,} R. R. Bowker, 1953. 4I7 p. \$20.00.

The importance of the private book collector to librarians and to the future of the libraries under their care is something too clearly evident and, indeed, too widely recognized to require either persuasive argument or elaborate demonstration.

One has but to reflect upon some of the names which adorn the façades and which are found engraved upon the bookplates of libraries large and small all across the land to realize that the private collector has in the past played, and in an increasingly prominent manner continues to play, a vital rôle in the development and enrichment of American libraries. 
To the academic librarian-and especially in times like these when the book dollar from the college or university treasury buys less and less while the ever-pressing need is for more and more-the potential usefulness of the private collector is a prospect bulging and bristling with alluring possibilities. And this is particularly true in the area of rarities and special collections.

Not every institution, of course, will find a munificent patron whose biblio-philanthropy will transform its rare books holdings from a handful of tattered, but venerable, volumes (in which the "s's look like f's") into a veritable treasure grove incased in gleaming leather and glittering gold, and where the shelflist reads like some sort of grand anniversary anthology of $M$ aggs and Rosenbach catalogs. But the practicing bibliophile who possesses a nice balance of acquisitive instinct and generous impulse, be he "ever so humble," can contribute something toward increasing the strength and the stature of a library's collections, and a group of such collectors, of varied interests and enthusiasms, can together do much.

The evident growing and widespread trend toward the establishment of Friends of the Library organizations is ample evidence of the validity and the success of this concept of persons joining together to make common cause of the requirement of increased library resources.

And, it should be pointed out, one of the perhaps surprising things which our colleges and universities are discovering as they go about the business of fostering these Friends of the Library groups and putting their Friends to work for them is that the collectors and others who are enthusiastically taking part in these activities are not necessarily alumni of the particular institutions concerned. An interest in a projected program and a sense of being themselves significant and appreciated, even if modest, participants are, among other things, often more important factors to these individuals than "old school" associations, if any.

The moral may readily be drawn from this that it behooves the academic librarian to know as many private book collectors as possible, be they alumni of his college or university or not, for they are all "fair game" -though, as the optimistic should be warned, by no means "sitting pigeons."

It is with a timeliness appropriate to the need for an up-to-date guide that the R. R. Bowker Company has published its tenth revised edition of Private Book Collectors, a register of collectors in both the United States and Canada, listing them (I) alphabetically by name, (2) geographically, and (3) according to collecting specialty or specialties. Within each of these three separate sections, collectors' addresses are given in full, and in the geographical part, a summary of all of an individual's collecting interests is provided.

Names for inclusion have been taken from the Bowker Company files and rolls of the leading "book societies, collectors' groups and private clubs," as well as having been suggested by libraries and collectors themselves. The present edition carries around 200 more names than the previous one (that of 1948), and it introduces for the first time a section of dealer-collectors, which runs to nearly 150 additional entries, for a grand total of over 2,000 collectors in all.

The directory is eminently useful as a reference tool to the librarian, whether it be in connection with the recruitment of gifts or new Friends of the Library, or in negotiating for loans of materials for exhibition purposes, or simply in determining how much collecting activity exists centering upon a particular author's works or relating to some specific subject or area.

The book itself suffers somewhat, but not seriously, from the handling of its catchwords and headings, which are in a few instances inaccurate, inconsistent, or confusing. Of some consequence in this latter connection is the disconcerting use of full names set in capitals and in normal order where the catchword happens to be an author's name. Because in such cases the first names are given equal prominence in typographical treatment and are not inverted with the surname, a person hurriedly fanning through the pages may find it somewhat difficult to be able to tell at a glance just where he is in the alphabetical sequence, his eye focusing upon the first name rather than the last, which is of course the important element. This is a feature of minor confusion that might easily have been eliminated or at least minimized.

An irregularity, however, that this reviewer, who is himself a New Hampshireman, finds 
difficult to comprehend and impossible to condone, is that New Jersey precedes New Hampshire in the alphabetical listing of states in the book's section locating collectors geographically. It is conceded, to be sure, that New Jersey may stand before New Hampshire in certain respects of a numerical character, but heretofore the alphabetical precedence of the Granite State has, I believe, gone unchallenged.

Private Book Collectors is, nevertheless, a valuable reference work of particular interest and utility to head librarians, special collections directors, curators of rare books and manuscripts, exhibits officers, and others responsible for the development of library collections.-Edward Connery Lathem, Dartmouth College Library.

\section{University of Virginia Library}

The University of Virginia Library, 18251950: Story of a Jeffersonian Foundation. By Harry Clemons. Foreword by Dumas Malone. Charlottesville, University of Virginia Library, 1954. xxii, 23 Ip., illustrated. \$5.00.

"They have nearly finished the Rotundathe Pillars of the Portico are completed and it greatly improves the appearance of the whole-The books are removed into the Library-and we have a very fine collection." So wrote Edgar Allan Poe to his foster father in Richmond in 1826 . The University of Virginia was then in its second session, and young Poe was a student there. It was indeed a fine collection. No university in America had started with a more carefully selected library. Thomas Jefferson, the founder of the University, had chosen most of the 8,000 volumes listed in the printed catalog issued in 1828 , and he had planned the book collection as carefully as he had planned the buildings.

For two decades after the highly commendable start, however, the library received scanty support. Some of the early prosperity was regained in the I85o's, but then came the war-and Reconstruction-and a disastrous fire in 1895 . The University remained open through it all, but not until its second century did the Library begin to attain the stature which Jefferson had envisioned for it.

The full story of the vicissitudes of the University of Virginia library is told here by
Harry Clemons who directed its activities so wisely from 1927 until his retirement in 1950. The library's history divides easily into five distinct periods, and each of these periods forms a chapter in the book.

Chapter I covers the founding period, from 1819 to 1826 , during which $\mathrm{Mr}$. Jefferson prepared lists of books to be ordered, secured funds for their purchase, and selected agents through whom they would be acquired.

The years from the death of the founder in 1826 to the beginning of the Civil War in $186 \mathrm{I}$ are described by Dumas Malone in the foreword as "a period of torpor." The University spent about $\$ 35,000$ for "books and apparatus" before 1826 , more than half of which certainly went for books. Funds for such purposes, however, were small or nonexistent in the two decades immediately following, and most of the books received came as gifts. But with a substantial increase in enrollment in the 1850 's came heavier demands for books and larger appropriations for their purchase. It was during this prosperous decade that a question about the adequacy of the rotunda for library purposes was first raised, a question which was to be heard many times in the eighty years which elapsed before permanent relief came in the form of the Alderman Library.

The third period, 1861-1895, began with a war and ended with a fire. The library had survived the hazards of war and Reconstruction, and broad progress was being achieved when fire reduced the book collections from 56,000 to 17,000 volumes, and destroyed most of those selected by Jefferson.

The significant feature of the fourth period, 1895-1925, was the extraordinary response of alumni and friends to requests for gifts. Within ten years after the rotunda fire, the collection had grown to 60,000 volumes. Noteworthy collections and handsome endowments were liberally sprinkled among the gifts, and by 1925 an endowment fund of $\$ 200,000$ for books had been accumulated. But greater demands were being made on the library, some from a department of graduate study whose program required that the library accept continuing responsibility for the selection and acquisition of material not hitherto necessary in an undergraduate curriculum.

The most remarkable progress of the library came during the administration of the 